\title{
Piotr Eysakowski
}

Badacz niezależny

Piotr.lysakowski@gazeta.pl

\section{Historia kłamstwa katyńskiego według Thomasa Urbana}

Thomas Urban, Katyń. Zbrodnia $i$ walka propagandowa wielkich mocarstw, przekł. E. Ziegler-Brodnicka, Bellona, Warszawa 2019, ss. 600.

„[...] Niemcy niewątpliwie mogą mieć pewne korzyści z tzw. sprawy Katynia i o korzyści te bardzo silnie zbiegali [...]. W Polsce Niemcom nie udało się nic, absolutnie nic. Nie dała Quislinga, nie dała żołnierza, nie dała robotnika, nie dała sfolgowania w akcji podziemnej [...]. Upowszechniła natomiast w społeczeństwie poczucie własnego interesu politycznego [...] Z próby politycznej początków 1943 r. Naród Polski wbrew intencjom Goebbelsa wychodzi z podsumowanym bilansem: Katyń i Oświęcim - jednacy wrogowie" 1 .

„Polskie Radio 10 maja 2020 13:00

W Twerze zatarto ślady po tablicach upamiętniających ofiary zbrodni katyńskiej. [...] białą farbą zamalowano plamy, które pozostały po tym, gdy ze ściany twerskiego Uniwersytetu Medycznego usunięto dwie pamiątkowe tablice. W ocenie rosyjskich historyków badających stalinowskie zbrodnie, to inspirowana działaniami władz próba zafałszowywania historii II wojny światowej"2.

Dokument „Katyń i propaganda Niemiecka” z „Kolekcji Czapskiego” z Instytutu Polskiego i Muzeum Generała Sikorskiego w Londynie sygn. Kol. 12/1/A/7 publikowany przeze mnie w pakiecie innych dokumentów w „Zeszytach Katyńskich” 1990, nr 1, s. 105-114 i w „Zeszytach Katyńskich" 2008, nr 23, s. 40/49.

2 Dyrektor OSW: Rosjanie nieopatrznie ujawnili istnienie protokołów dot. zbrodni katyńskiej - Polskie Radio, 12 maja 2020. Protokoły, dokumenty wykonawcze, akty wykonania wyroków. 
Zacznijmy ten tekst poświęcony wydanej ostatnio książce Thomasa Urbana ${ }^{3} \mathrm{Ka}$ tyń. Zbrodnia $i$ walka propagandowa wielkich mocarstw od podanych wyżej fragmentów: jeden to cytat z mojego artykułu zamieszczonego w „Zeszytach Katyńskich” (zob. przyp. 1). Przyczyna i ,wytłuszczenie” ostatniego zdania stanie się czytelne dla odbiorcy w dalszej części tego tekstu. Drugi to komunikat, który pojawił się na antenie PR jako groźne memento i pewnego rodzaju glossa do omawianej książki.

Teraz parę słów o kwestiach technicznych - praca liczy 710 stron podzielonych na 19 części (w tym dwie przedmowy do wydania niemieckiego i polskiego oraz posłowie), z załączonymi selektywną bibliografią, indeksem osób ${ }^{4}$ i charakterystyką źródeł, z których autor czerpał ilustracje. Konstrukcja książki odpowiada chronologii opisywanych zdarzeń i obejmuje okres od 1939 do 2012 roku, kiedy to ,...[w]raz z powrotem Putina na Kreml [...] dokumenty katyńskie w tym projekt Berii rozkazu egzekucji, zostały usunięte $\mathrm{z}$ internetowej strony archiwum prezydenta. Pytania polskich historyków do rosyjskich archiwów pozostały bez odpowiedzi. [...] Katyń pozostał więc zbrodnią bezkarną" (s. 696). Konstrukcja pracy jest pozornie zwarta, jednak po dokładnej jej analizie zaczynamy czuć zawrót głowy. Gdy spodziewamy się opisu zdarzeń w kolejności chronologicznej, nagle ni z tego ni z owego pojawiają się wątki „późniejsze” albo według fantazji autora „wcześniejsze”. Mimo to krok po kroku przeprowadza on niezorientowanego czytelnika przez trudną tematykę katyńską. Ta „podróż” byłaby jednak dużo łatwiejsza, gdyby nie „dziennikarskie” nawyki Urbana i problemy ze zrozumieniem pewnych szczególnych cech polskości (przyp. 3), do których należy także przywiązanie do katolicyzmus.

Autorowi w sposób wyraźny brak naukowej dyscypliny $-\mathrm{z}$ jednej strony jest to zaleta, z drugiej wada. Na dobrą sprawę każda z części książki mogłaby być osobną

Tymczasem Adam Eberhardt, dyrektor Ośrodka Studiów Wschodnich podaje, że „strona rosyjska przy okazji likwidacji tablic ku pamięci zamordowanych polskich oficerów w Twerze, nieopatrznie ujawniła fakt istnienia ponad 60 tomów protokołów dot. zbrodni katyńskiej, których istnieniu przez lata kategorycznie zaprzeczała" [...]. Więcej szczegółów przedstawił Marek Menkiszak, kierownik Zespołu Rosyjskiego OSW. „W zasobach archiwum Zarządu Federalnej Służby Kontrwywiadu (teraz FSB) obwodu twerskiego znajduje się ponad 60 tomów z protokołami posiedzeń trójki, dokumentami wykonawczymi z realizacji decyzji trójki, różną korespondencją na temat wykonywania wyroków, a także aktami ich wykonania" [...].

3 Opinie o historii Polski i kwestie rozumienia „spraw polskich” przez Thomasa Urbana dobrze charakteryzują kolejne publikacje: T. Urban, Niemcy i Jedwabne, „Tygodnik Powszechny” 2002, nr 18; idem, Niemieckie reparacje, Deutsche Welle, 27 sierpnia 2004; Thomas Urban miat grozić zwolnieniem Jankowskiemu i Rybińskiemu, „Rzeczpospolita”, 16 marca 2009; List Tomasza F. Krawczyka do Thomasa Urbana, Salon24, 1 maja 2010; „Süddeutsche Zeitung” o ksiażce „,My z Jedwabnego", Deutsche Welle, 8 września 2020. Zob. też przypis 5.

4 Indeks zawiera nazwiska „osób historycznych”, niestety nie wszystkich „ważnych” dla sprawy. Nie ma w nim natomiast wszystkich nazwisk pojawiających się w książce. Podobnie zresztą jest z bibliografią zawartą w pracy.

5 M. Drobinski, T. Urban, Johannes Paul II. Der Papst, der aus dem Osten kam, C.H. Beck, München 2020. Dodajmy do tego recenzję/opis tej pracy zamieszczoną w Deutsche Welle Polska, 18 maja 2020, Dwa oblicza Jana Pawła II. Rewolucjonista i reakcjonista ,[...] To, że Kościół katolicki przechodzi obecnie kryzys na całym świecie, ma swoje korzenie w pontyfikacie Jana Pawła II - piszą autorzy nowej biografii Karola Wojtyły [...]”. 
całością i nic na tym w mikroskali by nie straciła. Pytanie, na które nie potrafię odpowiedzieć jest takie: czy to „wina” autora, czy thumacza (o uwagach dotyczących thumaczenia i redakcji pracy niżej)!? Już na wstępie Urban ustawia dyskusję nad relacjami prasowymi dotyczącymi Katynia i wiarą Roosevelta w to, że zbrodnię popełnili Niemcy na płaszczyźnie naiwności i psychicznej trudności uwierzenia w niemiecką narrację „[... N Nie istnieją jednak poszlaki, że któryś z tych zachodnich korespondentów świadomie kłamał. [...] nie ma ani jednego śladu, że Roosevelt świadomie kazał szerzyć nieprawdę o Katyniu; dokumenty i wspomnienia współczesnych świadczą raczej o tym, że był absolutnie przekonany o winie Niemców, bo wierzył w rzetelność Stalina. [...] Także wśród Polaków byli publicyści broniący kremlowskiej wersji [...] Jednak nie ma dowodów potwierdzających tezę, że prosowieccy polscy publicyści świadomie wówczas pisali o Katyniu nieprawdę [...]" (s. 7/8, 18 i nast.).

Nie peszy autora, że wcześniej sam napisał to, co następuje ,[...] korespondenci angloamerykańscy, którzy w latach trzydziestych zjechali do Moskwy, z wielką sympatią opisywali budowę Związku Radzieckiego i przymykali oczy na ciemne strony. Okazało się kilkadziesiąt lat później, kilku z nich było na liście współpracowników albo informatorów NKWD" (s. 7). Dziś przecież wiedza o sowieckiej agenturze w otoczeniu Prezydenta USA, i miejscach istotnych dla funkcjonowania tego państwa, jest powszechna. Niejako przy okazji Urban zauważa też, że „,[...] patrząc [...] na pełną konfliktów historię stosunków polsko-rosyjskich, można stwierdzić, że Katyń jest synonimem dążenia do prawdy przeciwko kłamstwu i wolności przeciwko zniewoleniu. [...]" (s. 13). Odmiennie (i słusznie) od wielu polskich historyków niemiecki dziennikarz twierdzi, że w myśleniu Stalina ważne były „, [...] kategorie etniczne i narodowe [...]” (s. 14)

Jeśli chodzi o wspominaną wyżej konstrukcję pracy, to razi umieszczenie po części „Atak z zachodu i ze wschodu” fragmentu zatytułowanego „Cud nad Wisłą” i kontynuacja tej historii w kolejnych częściach poprzedzających chronologicznie wybuch wojny 1 września 1939 roku. Oczywiście autorowi wolno wszystko, ale w tak skonstruowanej pracy, jak omawiana (co zauważyłem wyżej), tego typu „wrzutka” powoduje bałagan poznawczy - szczególnie będzie to dotyczyło niemieckiego czytelnika, który ma o historii Polski pojęcie raczej niewielkie. Idąc tym tropem, można mieć do Urbana pretensje, że nie nazywa po imieniu „Operacji Polskiej” przeprowadzonej przez NKWD (rozkaz nr 00485 LKSW ZSSR z sierpnia 1937 roku) i wspomina 135 tys. „[...] Polaków uwięzionych $[\ldots] ”$, z których ,[...] prawie połowa została rozstrzelana [...]" (s. 31). Dziś wiemy, że standardową metodą, powtórzoną później w Katyniu (i innych miejscach), zabito w latach 1937-1938 ponad 111 tys. Polaków z ZSSR. W tym kontekście pojawia się też informacja o sowieckim mordzie na członkach KPP ,[...] którzy uciekli do Związku Radzieckiego przed prześladowaniami ze strony nacjonalistycznego kierownictwa w Warszawie. [...]" (s. 31). Nie trzeba tu wyjaśniać, że KPP w okresie międzywojennym była strukturą o nastawieniu antypaństwowym, niewahającą się stosować także metod terrorystycznych. Trudno więc mówić o prześladowaniach. Można mówić o brutalności władz wobec łamiących obowiązujące prawo. Musimy brać pod uwagę też i to, że stosunek do zdrajców był wtedy radykalnie inny niż dzisiaj, a Polska

\footnotetext{
A. Nowak, Prywatna zbrodnia Stalina, „Rzeczpospolita”, 30 listopada 2010,
} 
w traktowaniu tychże nie stanowiła szczególnie wyróżniającej się „,wyspy zła”, jeśli szło o likwidowanie działań skierowanych przeciwko obowiązującemu w RP porządkowi prawnemu.

Autor opisuje szczegółowo pierwsze miesiące niemieckiej władzy w okupowanej Polsce. Tu wątpliwość - narrację zaczyna od stwierdzenia „,...] SS polowała nie tylko na Żydów [...]" (s. 36), sugerując, że Polacy padali ofiarą zorganizowanego terroru niejako „dodatkowo” lub „przez przypadek”. Wypada przypomnieć, że początkowo głównym celem polityki hitlerowskiej byli wszyscy obywatele RP bez szczególnych „wyróżnień”. Wystarczy przejrzeć spisy zawarte w Sonderfahndungsbuch Polen, jakimi dysponowały niemieckie oddziały sił bezpieczeństwa wkraczające do Polski. Zezwierzęcony antysemityzm dopiero się rozpędzał ${ }^{8}$. Pojawia się kwestia mediów zależnych od okupanta, które dość szybko zaczęły funkcjonować na rynku okupowanego kraju, propagując niemiecki punkt widzenia wśród Polaków. Urban pisze o gazetach i słusznie twierdzi, że ,[...] wychwalały »nowy porządek« w Generalnym Gubernatorstwie. Polskie ugrupowania podziemne nazywały je »gadzinówkami«. Słowo to oddaje uniżoność, jaką zarzucano polskim współpracownikom redakcji. [...]" (s. 36). Otóż pojęcie to oddawało w sposób bezpośredni ,jad” intelektualny, kłamstwo, jakie „sączyły” w umysły Polaków takie tytuły jak „Goniec Krakowski”, „Nowy Kurier Warszawski” i inne. Kwestia „uniżoności”, będąc niewątpliwie ważna, pozostawała na dalszym planie.

Autor wspomina też o współpracy niemieckich i sowieckich służb specjalnych ,[...] Wysocy oficerowie gestapo (małą literą - w pracy znajdujemy sporo „niedoróbek” redakcyjnych - P.Ł.) spotykali się regularnie w celu omówienia współpracy. [...] Jak dotąd, nie znaleziono w archiwach żadnego protokołu dotyczącego treści rozmów na tych spotkaniach. [...] Z czasem wszelako polscy historycy wykluczyli, że obie strony wymieniały na ten temat informacje, a tym bardziej koordynowały akcje $[\ldots]$ obie strony [...] nadal sobie nie ufały. [...]" (s. 41/42). To, że nie znaleziono protokołów, nie jest niczym dziwnym, jeśli zna się algorytm funkcjonowania „służb”. Trudno jednak przejść do porządku dziennego nad koincydencją Intelligenzaktion (nie bardzo wiem skąd Urban wziął liczbę 5 tys. zamordowanych [s. 37], która była faktycznie wielokrotnie wyższa) z rozpoczęciem mordu katyńskiego 9 . Autor zresztą sam pisze, że państwowy bandytyzm rzadko pozostawia po sobie ślady.

To byłoby zgodne z wizją Urbana, w której Polacy wyolbrzymiają swoje historyczne cierpienia i niesłusznie uważają się za ,jedyne ofiary" niemieckiej agresji

8 J. Böhler, Zbrodnie Wehrmachtu w Polsce. Wrzesień 1939, Wojna totalna, thum. P. Pieńkowska-Wiederkehr, Znak, Kraków 2009. Proszę też zwrócić uwagę na wystawę „Groesste Haerte, Verbrechen der Wehrmacht in Polen, September/Oktober 1939 - Z największą brutalnością. Zbrodnie Wehrmachtu w Polsce [...]", której byłem współautorem (razem z Pawłem Kosińskim i Jochenem Boehlerem). Trzeba i można też sięgnąć po starszą literaturę: Sz. Datner, 55 dni Wehrmachtu w Polsce, Wydawnictwo Ministerstwa Obrony Narodowej, Warszawa 1967: Cz.Madajczyk, Polityka III Rzeszy w okupowanej Polsce, t. 1-2, Państwowe Wydawnictwo Naukowe, Warszawa 1970; idem, Die Okkupationspolitik Nazideutschlands in Polen 1939-1945, Akademie-Verlag, Berlin 1987.

9 M. Wardzyńska, Byt rok 1939. Operacja niemieckiej policji bezpieczeństwa w Polsce Intelligenzaktion, Instytut Pamięci Narodowej, Warszawa 2009. 
Trudno bez refleksji przyjąć liczbę wywiezionych w kolejnych deportacjach zarządzonych przez okupacyjne władze sowieckie na wschód obywateli RP. Autor pisze o milionie - przypomnijmy więc, że są szacunki mówiące o około 400 tys., 700 tys., są też i te dużo większe. Zasadnicza trudność polega na tym, że wszystkie są szacunkowe i bez dostępu do rosyjskich archiwów będzie niezwykle trudno zdefiniować do końca problem ${ }^{10}$. Generalnie $\mathrm{z}$ liczbami autor ma spory problem. W tekście, w różnych miejscach, pojawiają się szacunki, sporządzane według różnych systemów, dotyczące liczby zamkniętych, aresztowanych, wywiezionych, a w końcu pomordowanych - tworzy to wrażenie bałaganu (tak jak zaburzona chronologicznie narracja pracy). Wszystkie prowadzą w ostateczności do znanej nam liczby zabitych w Kozich Górach, Twerze, Charkowie i innych do dziś nieokreślonych precyzyjnie miejscach, wynoszącej ponad 21 tys. osób ${ }^{11}$.

Urban precyzyjnie opisuje życie uwięzionych w obozach NKWD. Zwraca przy tym uwagę na istotny szczegół - otóż jeśli popatrzymy na sprawę globalnie, to mimo intensywnie prowadzonej przez władze sowieckie (służby) akcji propagandowej ,[...] Śledczy z NKWD zajęli się Polakami nader gruntownie [...] oficerowie [...] zaproponowali jeńcom przejście do Armii Czerwonej [...] wielokrotnie mówili Polakom, że nie będzie państwa polskiego. Zarubin postawił pojednawczy akcent »Polska rzeczywiście powróci, ale to będzie inna Polska« [...]" (s. 54/56) nie udało się komunistom przekonać do panującego w ZSSR systemu większości oficerów zamkniętych w tychże obozach „[...] w Ostaszkowie pozyskali wśród jeńców 103 informatorów. [...]” (s. 57). Później w Griazowcu, jak i w „willi rozkoszy” miano zwerbować 30 donosicieli z 394 oficerów (s. 84). Atmosferę w Kozielsku i innych obozach autor określa jako przygnębiająca trudno się temu dziwić. Urban zwraca uwagę na działalność oświatową i życie duchowe uwięzionych - wspomina przy tym o Baruchu Steinbergu naczelnym rabinie WP.

Machina śmierci ruszyła w marcu 1940 roku. Warto byłoby jednak podać numery kolejnych decyzji i rozkazów prowadzących do tragicznego finału (2 marca 1940 roku Beria przekazał Stalinowi tajną notatkę nr 794/B, w której informował, że Polacy są »zdeklarowanymi i nie rokującymi nadziei poprawy wrogami władzy sowieckiej«, co powinno skutkować rozstrzelaniem. 5 marca wydano tajną decyzję $\mathrm{nr}$ P13/144 z zaproponowaną przez Berię treścią - był to faktyczny wyrok śmierci. 22 marca Beria wydał tajny rozkaz nr $00350 » O$ rozładowaniu więzień NKWD USRR i BSRR «). Opis samego mordu i zdefiniowanie jego bezpośrednich sprawców przeraża czytelnika - szczególnie tam, gdzie autor wspomina rzeźnika Błochina (s. 76/78 i nast.) - niby wszystko to wiemy, ale i tak jest przerażające (pamiętnik majora Solskiego, s. 70).

10 Tu zwróciłbym uwagę na publikacje Krzysztofa Jasiewicza, których Urban nie zauważa, można też sięgnąć do „Biuletynu Instytutu Pamięci Narodowej” 2005, nr 5-6 (52/53); Zbrodnia Katyńska. Pokonani w obozie zwycięzców.

11 Badając w latach osiemdziesiątych archiwum „Kolekcji Czapskiego” znajdującej się w Instytucie Generała Sikorskiego w Londynie natrafiłem na liczne informacje dotyczące możliwych miejsc pochówku pomordowanych Polaków. Niestety nie porobiłem wtedy ani kopii, ani szczegółowych notatek. Mimo upływu czasu i postępu w badaniach nie sądzę, by te ślady można było do końca lekceważyć. 
Ciekawy fragment to ten, w którym Urban wymienia polskich sportowców zamordowanych w Katyniu (8 olimpijczyków, s. 82). Już po zbrodni, w obliczu niemieckich sukcesów militarnych na zachodzie Europy Rosjanie wyselekcjonowali grupę ocalałych oficerów, którzy mieli być zarówno „bazą” dla planowanej polskiej jednostki przeznaczonej do możliwej konfrontacji z Niemcami, jak i donosicielami. Tu chciałbym zwrócić uwagę na pewną niezręczność tłumaczenia (nie jedyną zresztą) w pracy. Otóż część ze wspomnianych wojskowych miała spotykać się w „,czerwonym kącie” w obozie w Griazowcu (s. 85, 115, 117 o agenturze uplasowanej w polskich jednostkach i dezerterach w Armii Andersa jest też dalej). Mogli się spotykać, ale nie w „kącie” tylko w ,kąciku” (,krasnyj ugołok”).

Czas nieubłaganie płynął, a póki co sytuacja tych, którzy nie zostali zamordowani, nie ulegała zmianie. Nadal wobec trwającego sojuszu sowiecko-niemieckiego traktowani byli jako wrogowie, a Polski nigdy miało nie być (s. 93). Na marginesie akcji przeciwko polskim wojskowym prowadzono też prześladowania ,cywilów”. Znanymi ofiarami tejże padli mający już wcześniej fatalne doświadczenia z Sowietami Henryk Erlich i Wiktor Alter. Będąc prawdziwymi socjalistami, stali się wrogami Stalina i na dodatek optowali za powstaniem polskiej armii na terenie ZSSR i angażowali się w poszukiwania ,zaginionych” polskich oficerów. Był to marsz ku śmierci. Oskarżeni przez Mołotowa, który podpisał na nich wyrok za to, że ,[...] Erlich i Alter agitowali wśród żołnierzy armii Andersa, żeby nie walczyli z Niemcami, lecz przeciwko Armii Czerwonej [...]” (s. 118). Obaj stali się więc „spóźnionymi” ofiarami Katynia (s. 107 i wcześniej).

Wspomniane wyżej pomysły tworzenia w ZSSR polskiej jednostki i werbowanie wśród ocalałych agentury miały swój ciąg dalszy po zawarciu układu Sikorski-Majski. Intensywnie poszukiwano kadry oficerskiej dla tworzonego wojska. Stalin w rozmowach z Sikorskim, dramatycznie dopytującym się o ,zaginionych”, artykułował słynne „[...] Oni uciekli [...] do Mandżurii [...]”. Później wersję „ucieczkową” modyfikowano. Miała nastąpić na tereny zajmowane przez Niemców. Kłamstwo goniło kłamstwo w trakcie poszukiwań i rozmów z tymi, którzy prowadzili te poszukiwania ze strony polskiej (Józef Czapski, s. 109 i nast.). Było to skuteczne, a możliwość popełnienia zbrodni tak niewyobrażalna z punktu widzenia „normalnego" postrzegania polityki i kontaktów międzynarodowych, że Sikorski nie chciał w „coś takiego uwierzyć”, zakładając według Urbana dobrą wolę Stalina (s. 113). Jeśliby tak w rzeczywistości miało być, byłoby to dyskwalifikujące dla niego jako polityka prowadzącego sprawy polskie.

Ważne miejsce w opowieści autora zajmuje wątek niemiecki sprawy katyńskiej. Istotne nazwiska w tej narracji to Friedrich Ahrens, Rudolf-Christoph von Gersdorff, Fabian von Schlaebendorff, Hennig von Tresckow, Reinhart von Eichborn, Ulrich von Hassel niemieccy oficerowie i dyplomaci, którzy przyczynili się do nagłośnienia mordu w Kozich Górach i odegrali później istotną rolę w Norymberdze oraz spiskowali przeciwko Hitlerowi (s. 122/128, 225 i nast.). Nie jestem specjalistą od kwestii niemieckiego ruchu oporu. Zdaje się jednak, że korzystając z okazji Urban próbuje „dowartościować” ludzi występujących przeciwko „Führerowi”. Niewątpliwe jest to potrzebne, nie jestem jednak pewien, czy służy to pracy dotyczącej Katynia. Abstrahuję tu od ich osobistego heroizmu, zwracam jednak uwagę na to, że faktyczny opór przeciwko reżimowi 
nie był tak powszechny, jak uważa niemiecki publicysta. W końcu jednak to książka Urbana i on bierze za jej narrację odpowiedzialność na siebie.

Po odkryciu miejsc mordu i zwłok ich stan badał Gerhard Buhtz. Z jego analiz wynikało jasno, że zbrodni dokonali Sowieci. Jednym z dowodów ich sprawstwa oprócz ran postrzałowych charakterystycznych dla metod działania sowieckich organów bezpieczeństwa były też ślady po pchnięciach charakterystycznym bagnetem mocowanym do karabinu „Mosin wz. 1891”. Tu uwaga do tłumaczenia - tekst opisujący powyższe ustalenie brzmi ,[...] Jako kolejny dowód sowieckiego sprawstwa jego raport przytacza rany kłute od bagnetu z czterema ostrzami [...]" (s. 134, na s. 353 bagnety te opisane są już prawidłowo jako „czworokątne”). Warto w tym miejscu zapytać o jakość pracy redakcyjnej.

Ciekawe są w tekście pracy liczne odniesienia do rosyjskich świadków mordu i tych, którzy ośmielili się zeznawać przed Niemcami o tym, co wiedzieli o zbrodni (Borys Mienszagin, Siergiej Maksymow, Iwan Kriwoziercew, Borys Bazylewski). Ich późniejsze losy były dramatyczne. Przy okazji wypływa kwestia funkcjonariuszy, którzy mieli znaleźć się w składzie „komand śmieci”. Urban wyklucza z szeregu tychże, pojawiające się w hitlerowskiej prasie takie osoby jak: Lew Rybak, Chaim Finberg, Abram Borysowicz i Paweł Borodinski. Twierdzi przy tym, że fakt, iż znalazły się one w propagandowych publikacjach mediów III Rzeszy tylko i wyłącznie z tego powo$\mathrm{du}, \mathrm{izz},[\ldots]$ treść najwidoczniej została nakazana przez nazistowską propagandę [...]" (s. 142, 166, 167, 207 i nast.). Równocześnie nie zadaje sobie trudu, by sięgnąć szerzej do literatury, w której znajdą się sugestie przeciwne do formułowanych przez niego ${ }^{12}$.

Po odkryciu mogił w Kozich Górach wydarzenia toczyły się w oszałamiającym tempie i doprowadziły do sytuacji, w której rząd RP musiał upomnieć się po raz kolejny o prawdę. Jak to zwykle w grze z „gangsterami”, musiał tę rozgrywkę przegrać. Nie dość tego, że Sowieci i idący na ich pasku komuniści oskarżali Sikorskiego o świadomą kolaborację z Niemcami (s. 169), to jeszcze wyraźnie zły na Polaków Churchill pozwalał sobie na niewybredne ataki pod ich adresem. Prosił równocześnie Moskwę, chcąc zachować jedność w obozie aliantów, by Rosjanie nie zrywali stosunków z władzami RP (s. 170/171). Obiektywnie służyło to wszystko antypolskiej propagandzie uprawianej przez Kreml (s.172). W informacyjnym szumie, wśród politycznych połajanek, fakty dostrzegały tylko media w Szwajcarii. Autor podkreśla to mocno.

Urban opisuje wizytę polskiej delegacji w Katyniu. Wspominając członków tej grupy, nie uwzględnia w niej osoby Jana Emila Skiwskiego (chyba że przeoczyłem, ale Skiwski nie pojawia się nawet $\mathrm{w}$ indeksie osób na końcu książki ${ }^{13}$. Opisuje przy tym

12 J.K. Zawodny, Katyń, Editions Spotkania, Paryż 1989, Aneks, dokument nr 2 „Częściowa lista personelu NKWD, który na wiosnę 1940 roku brał udział w planowaniu zbrodni i zamordowaniu 15000 polskich jeńców wojennych w Związku Sowieckim", s. 165/166.

13 Przy okazji dwa słowa o powojennych losach J.E. Skiwskiego - w czerwcu 1949 roku przed sądem rozpoczęto sprawę krakowskiego tygodnika „Przełom” (wydawany od kwietnia 1944 do stycznia 1945 roku). Skiwski sądzony był zaocznie. Pobyt tam musiał wyzwolić w nim mocne antysowieckie emocje, pisał bowiem w pierwszym numerze „Przełomu” co następuje: ,[...] kto podminowuje tor, po którym ma przejść niemiecki pociąg z wojskiem lub amunicją, [...] lub podpala wojskowy magazyn aprowizacyjny, ten działa na korzyść nacierającej Armii Czerwonej. 
dobrze atmosferę panującą wśród Polaków odwiedzających miejsce kaźni. Wątpliwości, jakie były udziałem uczestniczących w tejże, kontakty z Niemcami, którzy byli wstrząśnięci tym, co zobaczyli w Kozich Górach (s. 190). Sporym utrudnieniem prac ekshumacyjnych były „wizyty” grup żołnierzy Wehrmachtu przywożonych na miejsce niewątpliwie po to, by pokazać im, co może ich czekać w przypadku zwycięstwa Sowietów (s. 200). Pojawili się tam także polscy oficerowie przywożeni z oflagów. Wywierano na nich presję i wikłano $\mathrm{w}$ propagandowe manipulacje. Charakterystyczna, choć niereprezentatywna dla ogółu, jest tu opinia Leona Kruczkowskiego „,...] Prowokacja katyńska w znacznej mierze [...] spełniła nadzieje pokładane w niej przez Goebbelsa. Do marca 1943 roku [...] sympatie do Związku Radzieckiego [...], punkt szczytowy osiągnęły w okresie Stalingradu, Katyń przyniósł w tym względzie radykalną zmianę [...]" (s. 204). Wbrew niemieckim oczekiwaniom nic, w ostatecznym rozrachunku, nie dała też wizyta w Katyniu Leona Kozłowskiego, który pojechał tam ,,[...] za pośrednictwem rosyjskich emigrantów z Antikominternu [Anty... P.Ł. redakcja się kłania]..." (s. 212).

W części zatytułowanej „Listy proskrypcyjne polskich świadków” Urban zamieszcza fragment materiału, który znalazłem lata temu w Instytucie im. Generała Sikorskiego w Londynie i później opublikowałem (zob. przyp. 1). Zwracam na to uwagę z tego powodu, że Urban omawia dokument jako analizę „rządu emigracyjnego" opisującą cele „kampanii katyńskiej Goebbelsa” (s. 214). Problem w tym, że była to analiza wywiadowcza przekazana na ręce Rządu RP z kraju. Niby nic nie znaczący szczegól, ale ... Autor w przypisie wskazuje miejsce, w którym dokument był publikowany i dokładnie opisany - skąd więc pomyłka? Nieco dalej (s. 221) podawany jest dalszy ciąg tego materiału, $\mathrm{z}$ tego powodu zamieściłem na początku niniejszego tekstu fragment brzmiący w oryginale następująco „,[...] Katyń i Oświęcim - jednacy wrogowie $[\ldots] ”$. W tekście omawianej pracy brzmi on ,„[...] Katyń i Oświęcim - tacy sami wrogowie [...]”. Znowu niby nic, ale wyraźny dowód na to, że tłumacz nie sięgnął do oryginału tekstu źródłowego.

Autor szeroko opisuje działania goebbelsowskiego ProMi, mające na celu rozbicie sojuszu państw zachodnich z ZSSR. Ważnym elementem miały być tu wspominane już wyżej „katyńskie wycieczki” lekarzy, intelektualistów, osobistości życia politycznego

Każdy taki akt jest wiązaniem [...] tych sił, które wraz ze swoimi towarzyszami na wschodzie powołane są do spełnienia epokowej misji odegnania czerwonej szarańczy”. Proces zakończył się wyrokami skazującymi. Skiwski otrzymał „dożywotkę”. Przy okazji, jako ciekawostkę, warto przytoczyć fragment memoriału, jaki Skiwski przedłożył władzom Generalnego Gubernatorstwa (na ręce Josefa Bühlera). Pisał tam co następuje: ,[...] Konieczne jest [...] popularyzowanie w słowie i w piśmie pojęcia o kierowniczym narodzie w Europie - Niemcach. Musi istnieć w Europie jedno państwo wielonarodowe pod kierownictwem Niemiec. Skoro faszyzm nie ma za sobą dziesiątków ludów europejskich, a skoro zależy na tym, aby ten faszyzm przy władzy utrzymać, należy wszelkimi sposobami głosić, że nie potrzeba żadnej suwerenności państwowej. Niech będzie jednolita Europa [...]". Skiwskiego oskarżał prokurator Gustaw Auscaler, który 20 października 1952 roku w imieniu Sądu Najwyższego podtrzymał wyrok śmierci w odniesieniu do Generała „Nila”. Materiały do „sprawy” Skiwskiego zaczerpnąłem z numerów „Życia Warszawy” i „Głosu Ludu” z roku 1949. Warto też rzucić okiem na tekst z „Gońca Krakowskiego”, Czerwony bies atakuje kulturę.Wywiad z literatem Skiwskim na temat Katynia, 24-27 kwietnia 1943. 
sojuszników Hitlera i państw neutralnych. Nie udawało się to bez problemów. Ostatecznie w Kozich Górach znaleźli się przedstawiciele z Belgii, Bułgarii, Chorwacji, Danii, Finlandii, Holandii, Protektoratu Czech i Moraw, Rumunii, Węgier i Szwajcarii. Otrzymujemy w tym miejscu szczegółowe „notki” biograficzne wszystkich uczestników międzynarodowej komisji badającej zbrodnię. Zasadniczo nikt $\mathrm{z}$ nich nie wątpił w winę Rosjan, choć podobno reprezentant rządu Vichy André Costedoat nie chciał złożyć swojego podpisu pod raportem, sporządzonym po wizycie i oględzinach zwłok pomordowanych (s. 236). Wśród „katyńskich” lekarzy należy w ślad za Urbanem przypomnieć Helge Tramsena ${ }^{14}$, który zapłacił za głoszoną przez siebie prawdę o Katyniu najwyższą cenę - stracił (najprawdopodobniej w efekcie mordu) córkę, która zginęła w Warszawie w 1970 roku $^{15}$ (s. 239/240 i nast.). Lekarzy wycofujących się ze swoich ustaleń pod wpływem sowieckich i politycznych nacisków nie nam tu oceniać. Walczyli o swoje życie i życie swoich bliskich. Katyń odwiedzali nie tylko medycy. Byli tam również dziennikarze. Część z nich jadąc na miejsce zbrodni była przekonana, że będą świadkami kolejnej niemieckiej propagandowej hucpy. Wobec zderzenia z potwornymi znaleziskami to przekonane ulegało zmianie. Interesujące, ale powtarzającym się argumentem przeciwko niemieckiej wersji było to, że ,[...] pomordowani Polacy mieli na nogach swoje buty [...] było powszechnie wiadome, że czerwonoarmiści zdejmowali buty poległym [...]" (s. 246). Zdumienie wywołało niespodziane pojawienie się na stole sekcyjnym zwłok kobiety (Janiny Lewandowskiej). Wspominany wyżej Helge Tramsen zauważył, że musiała bronić się przed egzekucją. Była związana, a głowę miała owiniętą workiem (s. 248/249).

Opisując Katyń, hiszpańscy publicyści odwoływali się do zbrodni popełnianych przez „republikanów” w czasie hiszpańskiej wojny domowej. Tu kolejna uwaga dotycząca edycji pracy - na stronie 250 wymieniany jest tytuł prawicowej (falangistowskiej) gazety „Arriba”. Kilka linijek niżej pojawia się ona jako „Arria” (praca redakcyjna P.Ł.). Urban wspomina też o „konwersji” Orwella, która była efektem doświadczeń właśnie konfliktu w Hiszpanii i tego, co tam obserwował, co rzutowało na jego późniejszą postawę wobec kwestii katyńskiej.

Wizyty w miejscu zbrodni skutkowały sporą liczbą publikacji. Oprócz materiałów prasowych pojawiały się i wydawnictwa książkowe. I tak np. Ernesto Gimenez Caballero, hiszpański oryginał nienawidzący w sposób podobny zarówno bolszewizmu, jak i kapitalizmu, zaangażował się w niemiecką akcję, publikując broszurę La Matanza de

14 Autor nie podaje w tekście swojej książki informacji o tym, że ,[...] Badacze wywieźli także z Katynia m.in. fragmenty sznurów, którymi były skrępowane ręce oficerów, naramienniki, guziki, a dr Helge Tramsen, duński chirurg, wywiózł czaszkę jednego z zamordowanych [...] Dr Tramsen [...] dostał zgodę duńskiego ruchu oporu na wyjazd do Katynia i [...] przemycił do Danii przestrzeloną czaszkę jednego z zamordowanych, mjr Ludwika Szymańskiego. [...] dopiero po 60 latach udało się odnaleźć zamieszkałego w Australii syna oficera, Jerzego [...] . Na jego prośbę szczątki ojca zostały złożone w kaplicy katyńskiej w Katedrze Polowej Wojska Polskiego [...]" - fragmenty z wywiadu z Tadeuszem Wolszą, Świadczyli o zbrodni Sowietów, „Polska Zbrojna”, 13 kwietnia 2019. To istotne niedopatrzenie.

15 A. Zechenter, Zemsta za prawdę o Katyniu - losy ekspertów, „Nasz Dziennik”, 15 kwietnia 2016. 
Katyn. Vision sobre Russia, podkreślając przy tym swą sympatię dla Polski „,...] Niemieccy żołnierze z szacunkiem formowali się na polanie. W wojskowym szyku stały komanda pogrzebowe dla uczczenia hekatomby [...] Biedna Polsko! [...] Zawsze próbowaliśmy oddzielić Polskę od jej najgorszych wrogów: od tych wszystkich, którzy zawsze zmierzali do tego, żeby zrobić z Polski bałkańskie gniazdo os, bagnet wbity w bok Niemiec. [...]” (s. 259/260). Podziw dla hitlerowskich Niemiec i żal nad losem „zdradzonej Polski" pojawiał się w publicystyce belgijskiej (s. 260 i nast.). Ornulf Tigerstedt przewodniczący fińskiego PEN Clubu, który znalazł się w Katyniu, wyrażał obawę, że los Polaków może stać się udziałem fińskiej inteligencji, gdyby jego kraj znalazł się pod sowiecką okupacją. Robert Brasillach konludował ,[...] Oni zrozumieli, że Polacy nienawidzą bolszewizmu [...] i że poza Piłsudskim polska historia zawsze była antyrosyjska. Sowieci wyciągnęli z tego stwierdzenia logiczny wniosek: pozbawili polską elitę głowy, $[\ldots]$ Polacy stali się ofiarami własnych »nieostrożnych przywódców i bolszewickiego barbarzyństwa« [...]” (s. 275).

W przestrzeni politycznej, jak i medialnej toczyła się walka propagandowa o to, kto zostanie ostatecznie uznany winnym potworności popełnionej w Katyniu. Problem polegał na tym, że wobec ogromu niemieckich zbrodni popełnionych od chwili rozpoczęcia wojny trudno było nawet wobec twardych dowodów sowieckiej potworności w sposób jednoznaczny stwierdzić winę ZSSR. Do tego dochodziła rosyjska dezinformacja - wpływ „pożytecznych idiotów” i agentury. Do dziś nie jestem pewien, do której kategorii zaliczyć Josepha E. Daviesa, ambasadora USA w Moskwie (s. 288, 297, 301, 305, 309 i nast.), czy Dorothy Thompson (s. 299). Wpływu tego pierwszego na Prezydenta USA nie można nie doceniać i dobrze, że autor poświęca tej postaci sporo miejsca. Biorąc pod uwagę powyższe, nie powinny dziwić trudności, jakie napotykał Sikorski w kontaktach z Rooseveltem, gdy chodziło o sprawiedliwą ocenę stosunku Sowietów do Polski. Nie bez znaczenia była w tym przypadku wewnętrzna rywalizacja Odziałów SS z innymi służbami. Urban pokazuje nam też działania „katyńskie” Ernsta Hanfstaengla „Putzi” (s. 290, na s. 298 występujący jako „Puti” kolejna uwaga do redakcji), „pianisty Hitlera” początkowo zafascynowanego Führerem później zbiega z III Rzeszy.

Opisując postawę brytyjskiego Foregin Office, tam gdzie wzmiankuje o raporcie sekretarza stanu Alexandra Cadogana, w którym tenże wspomina o sprawozdaniu Owena O'Malleya, autor pisze o niepewności brytyjskich ekspertów co do kwestii winy „za” Katyń. Ja przytoczone fragmenty traktowałbym nie jako wątpliwości, a raczej refleksję nad tym, jak mogą się ułożyć polsko-rosyjskie stosunki po zakończeniu wojny i jak, z moralnego punktu widzenia, można wymagać od Polaków dobrej woli wobec wschodniego sąsiada „,[...] Jak Polacy mogą kiedykolwiek żyć razem z Rosjanami polubownie i, skoro tolerowaliśmy ich zbrodni [! redakcja tekstu - P.Ł.], jak możemy rozmawiać z Rosjanami o egzekucjach niemieckich zbrodniarzy wojennych?” (s. 314). Nie zmieniało to w żadnym wypadku podejścia do sprawy współpracy z Sowietami ze strony Churchilla, który wręcz żądał od Polaków milczenia w kwestii Katynia. Dodajmy, że brytyjski premier w 1943 roku w zasadzie miał już pewność, że zrabowane Polsce w 1939 roku Kresy Wschodnie nigdy do niej nie wrócą. Położenie rządu RP na wychodźstwie pogorszył radykalnie dramat z 4 lipca 1943 roku, jaki zdarzył się w Gibraltarze. Nie zajmując wyraźnego stanowiska w tej sprawie, Urban nie zwraca także 
uwagi i na to, że ostatecznie, patrząc na sprawę perspektywicznie, największe korzyści ze zgonu generała mieli Sowieci i polscy komuniści, namaszczeni przez tych ostatnich na przyszłych rządców „ludowej Polski”.

Część informacji o Katyniu napływała do administracji USA i z zupełnie nieoczekiwanych źródeł (s. 333, 334), a mianowicie od skłóconych ze sobą agentów NKWD funkcjonujących na terenie Stanów Zjednoczonych. Na „dramacie katyńskim” rosły też komunistyczne kariery w polskich strukturach formowanych przez Sowietów. Urban wspomina tu o Berlingu (s. 335 i nast.). Cała zresztą „Polska Ludowa” wyrosła na grobach pomordowanych w Kozich Górach. Grzech został zaakceptowany przez aliantów już w Teheranie. Tam Stalin okrutnie żartował, że za masakrę polskich oficerów zrewanżuje się mordując niemieckich (wspominał o 40 lub 50 tys., s. 342). Ciekawe, czy był to rzeczywiście żart i jak potoczyłyby się losy Niemców wziętych przez Rosjan do niewoli, gdyby „żarcik” spotkał się z aprobatą słuchającego go Churchilla.

Śledząc działania komisji Burdenki zauważymy, że jej raport wspomina o 11 tys. zabitych Polaków. Rosjanie zastosowali w tym miejscu taką samą metodę, jak Niemcy w 1943 roku. Przypisali swoim antagonistom mord na wszystkich zaginionych, by w ten sposób zamknąć sprawę raz na zawsze, bez faktycznego sprawdzania liczby zwłok w Kozich Górach. Urban zakłada, że Burdenko przed przystąpieniem do prac w Katyniu nie był do końca zaznajomiony ze stanem faktycznym sprawy, nie wyklucza to jednak tego, że był świadomy niebezpieczeństwa, jakie przynosiła sprawowana przez niego w danym momencie funkcja i wnioski, do jakich jego badania prowadziły. Nie wiem, czy to dobre założenie!? Wokół komisji, podstawionych świadków i obserwujących „to” wszystko wścibskich dziennikarzy amerykańskich kręcili się także wysłannicy polskich komunistów (Jerzy Borejsza s. 364, 382 i nast.). Dociekliwość Amerykanów musiała irytować sowieckich oficjeli, którzy zmuszeni byli odpowiadać na „tendencyjne” pytania w stylu: jak to się stało, że zgładzeni przez Niemców w lecie oficerowie polscy nosili zimowe ubrania. Te wątpliwości studziły mocno przyjazną atmosferę (s. 379). Nie przeszkadzało to twierdzić wspomnianemu wyżej Borejszy, że Amerykanie i Brytyjczycy nie mieli cienia wątpliwości co do tego, kto był sprawcą mordu (s. 382). „[...] Lauterbach przytoczył kolejny, jego zdaniem niezbity dowód niemieckiego sprawstwa; polscy oficerowie zostało zakopani w masowych grobach w butach - gdyby sprawcami byli Rosjanie [...] zdjęliby buty ofiarom [...] Nikt nigdy nie wątpił, że zrobili to Niemcy [...]” (s.385). John Gibbons z „Daily Worker” w ślad za „świadkami” Anną Aleksiejewą i Wiktorem Prozrowskim definiował Katyń jako ,[...] największe niemieckie fałszerstwo podczas wojny [...]" (s. 386). Oprócz tak zdecydowanych opinii pojawiały się dokumenty (można mieć tu wątpliwości, czy nie były to wyprodukowane przez NKWD apokryfy, s. 393), potwierdzające niemiecką winę. Bankiet urządzony na Kremlu przez Mołotowa kończący wizytę dziennikarzy w Rosji był dla nich swoistego rodzaju nagrodą za „właściwe” relacje z miejsca zbrodni. Mieli też możliwość bliższego poznania Wasilewskiej i Berlinga. Oboje byli gorącymi orędownikami tezy o niemieckim sprawstwie mordu (s. 396). Dla wzmocnienia sowieckiego przekazu zorganizowano nawet mszę (styczeń 1944) w Katyniu, odprawianą przez księdza Wilhelma Kubsza. Po tejże okazało się, że jakiekolwiek rozmowy Polaków z miejscowymi są niemożliwe. Abstrahując już od tego, że część z nich (w tym jeden z głównych 
świadków mordu Parfien Kisieliew) ni z tego, ni z owego „zniknęli” (lub zostali zamordowani, jak Iwan Kriwoziercew) i już nigdy się nie pojawili wśród żywych „,...] Tokariew, który brał udział w masowych egzekucjach Polaków w Kalininie, zeznał, że Moskwa wydała rozkaz »aby nie pozostawiać przy życiu ani jednego świadka« [...]" (s. 400). Nie znajdziemy śladu po tych wydarzeniach w relacjach aktywnego wtedy Jerzego Borejszy. Dziś zdaje się, że jego działalność była przygotowaniem gruntu pod planowane przez komunistów działania „wyjaśniające” Katyń i pokazowe procesy polityczne związane z tą kwestią (s. 428/429, Henryk Świątkowski). Niezależnie jednak od punktu widzenia, jaki reprezentowali poszczególni politycy i ich zaplecze, przeważała opinia, że sprawę należy „zostawić” w imię wspólnego dobra - zwycięstwa nad III Rzeszą. Wątpliwości zaczęto artykułować lata później ${ }^{16}$.

Po zakończeniu wojny rozpoczęło się polowanie na świadków i uczestników wyjazdów do Katynia organizowanych przez Niemców. Ofiarami swojej wcześniejszej aktywności padli Marko Markow, František Hajek, Edward Miloslavic (zaocznie skazany na śmierć), Alexandru Birkle (zaocznie skazany na 20 lat obozu pracy przymusowej), František Subik, Herman Maximilien de Burlet, François Naville i inni. Oceniał to Vicenzo Palmieri ,[...] Prawdopodobnie zrobiłbym to samo, gdyby Neapol został oswobodzony przez Armię Czerwoną [...]" (cytat nie jest skończony - znów kłania się redakcja pracy - s. 440). Uzupełniając obraz dodajmy, że co prawda Armia Czerwona nie zawędrowała do Neapolu, ale miejscowi komuniści usiłowali (w uzgodnieniu z ambasadą ZSSR) wyrzucić Palmieriego z pracy na uniwersytecie. Ofiarą prześladowań stał się też Fin Ornulf Tigerstedt „faszysta i zbrodniarz wojenny” (s. 449), dożywocie dostał Flamand Ferdinand Verncnocke (obniżone później do szesnastu lat, skróconych ostatecznie do sześciu). Roberta Brasillacha skazano na śmierć (s. 450) za szerzenie propagandy goebbelsowskiej (odwoływano się przy tym także do jego opisów pobytu w Katyniu). Pisał on w swoich wspomnieniach ,[...] są ludzie wyobrażający sobie, że Katyń to blef. Ale czy Sowieci zerwaliby z polską emigracją w Londynie, gdyby chodziło o blef? [...]" (s. 451).

Wobec zbliżającego się procesu w Norymberdze Sowieci rozpoczęli ofensywę mającą na celu ostateczne zamknięcie „sprawy Katynia” i przerzucenie odpowiedzialności za zbrodnię na Niemców. Różne „zachodnie” tytuły prasowe przynosiły codziennie częściowo inspirowane rewelacje. „Le Monde” cytował list Gregora Slowenczika, znaleziony rzekomo przez ocalałą z Auschwitz Żydówkę, zamieszkującą po wojnie dom, w którym wcześniej mieszkał Slowenczik ,[...] Mój największy sukces dzisiaj: zerwanie dyplomatycznych stosunków ZSRR - Polska. [...]" (s. 463). Rosjanie zażądali też, by na wokandzie znalazł się również Katyń „, [...] jako zbrodnia dokonana na Polakach przez Niemców [...]”" (s. 465). Początkowo zdawało się, że konfiguracja polityczna sprzyjała ZSSR i zaplanowanemu scenariuszowi - Urban odwołuje się w tym miejscu do „procesu szesnastu”, prowadzonego także według określonego algorytmu przez sowieckiego oskarżyciela z Norymbergi generała porucznika Romana Rudenkę.

16 Autor wspomina tu Homera Smitha, który w swojej pracy Black Man in Red Russia pytał ,[...] Jaką korzyść mogli zyskać Hitler i Goebbels z ujawnienia zbrodni, skoro w tym odosobnionym i zarosłym lesie grób mógł pozostać niewykryty przez wiele lat [...]”. 
W tym miejscu na marginesie warto przypomnieć w ślad za Urbanem równie heroiczne, co bezskuteczne wysiłki George'a Orwella w obronie prawdy o Katyniu (de facto w obronie Polski, s. 472/486). Wbrew sowieckim nadziejom kwestii katyńskiej nie udało się ,poprowadzić” w zaplanowanym kierunku, sąd był bowiem ,rzeczywistym sądem" i przesłuchiwał (wbrew oczekiwaniom Rudenki, s. 485) niemieckich świadków (którzy byli chronieni przez Amerykanów) bezstronnie. Pozaprawne działania Rudenki wywołały obronę Niemców oskarżanych o niepopełnioną zbrodnię, której efektem było przypomnienie paktu Ribbentrop-Mołotow wraz z dodatkowymi protokołami. Wywoływaniu tego tematu miał zapobiec generał major Nikołaj Zoria (asystent Rudenki). Kilka dni po nieudanej akcji miał popełnić samobójstwo (pojawiają się też opinie, że został zamordowany przez „swoich” właśnie za nieudolność, s. 474, 641 i nast.).

Warto przypomnieć, że w przestrzeni medialnej ponownie pojawiła się, wspominana wyżej, „kwestia butów” polskich oficerów, jako argument za sprawstwem Niemców. Gösta von Uexküll niemiecki dziennikarz, opisując w szwajcarskim „Die Tat” rozmowę z Amerykaninem twierdzącym, że „,[..] Katyń to zbrodnia niemiecka bo buty [...]” konkludował ,[... Pozornie argument nie do zbicia, ale tylko pozornie, bo nikt w Rosji nie posiada tak dobrego obuwia jak NKWD [...]" (s. 491, Uexküll był też pierwszym dziennikarzem, który upominał się o zdefiniowanie „Katynia” jak zbrodni sowieckiej, s. 520). Z wolna konkludowano, że Rosjanie nie wykorzystali szansy „,[...] oczyszczenia się z tego strasznego i szeroko rozpowszechnionego oskarżenia [...]" (Churchill, s. 504). Nie udało się w Norymberdze - w związku z tym niejako równolegle organizowano w Sowietach procesy „zbrodniarzy wojennych”, w których pojawiali się niemieccy świadkowie (Arno Duerre - skazany na 15 lat) mordu popełnionego na Polakach przez SS w Katyniu (s. 475).

Pojawiało się coraz więcej osób chcących prawdy o zbrodni (Julius Epstein). W ten proces włączyli się dyplomaci - Arthur Bliss Lane ambasador amerykański w Warszawie był jednym z nich. Komisja Maddena, raport Van Vlieta, Kathleen Harriman i jej zmieniające się relacje z Katynia ,[...] Z zakłopotaniem musiała przyznać, że brak jej kompetencji do oceny sowieckiej prezentacji w Katyniu. [...] w swojej relacji z 1944 roku była pewna, że dowody niemieckiej winy są przytłaczające [...]” (s. 541), to „słupy milowe" dla ewoluujących wizji odpowiedzialności za zbrodnię. Z upływem czasu pojawiały się coraz to ciekawsze fakty dotyczące sprawstwa katyńskiego „,...] Sensację wzbudziło przesłuchanie (przed Komisją Maddena) byłego polskiego oficera, który twierdził, że w obozie [...] rozmawiał o Katyniu z Jakowem Dżugaszwilim [...] synem Stalina [...] który [...] jakoby usprawiedliwiał zamordowanie polskich oficerów słowami: »To była inteligencja, dla nas najgroźniejszy element, ich trzeba było eliminować«...” (s. 550). Stopniowo okazywało się też, że amerykański Departament Stanu wcześniej absolutnie lekceważył sygnały sowieckiej nielojalności i kłamstw w sprawie. Łączyło się to z brakiem przyzwoitego traktowania słabszego sojusznika Ameryki Polski. Wynikało z tego narastające przekonanie, że ,[...] USA ze swoim stosunkiem do Sowietów znalazły się w tym tragicznym położeniu, że wygrały wojnę, ale przegrały pokój [...]” (s. 560). „Katyńskie” konkluzje Komisji Maddena wywołały alergiczną reakcję w ZSSR i krajach „obozu demokracji ludowej”. 
$\mathrm{Na}$ marginesie tych awantur gasły kolejne „gwiazdy” komunistycznej propagandy, co jednak nie zmieniało ich stosunku do przedmiotu sporu (Jerzy Borejsza, s. 576/577), czyli prawdy i polskiej suwerenności. Pisząc o osobistej „tragedii” komunistycznego aparatczyka, który postanowił stać się „niepokornym”, Urban wspomina o represjach ze strony władz, jakie spadały na tych, którzy mieli odwagę publicznie wspominać o sowieckich sprawcach mordu, jak i szykanach wobec rodzin znanych ofiar (generała Mieczysława Smorawińskiego). Niestety w tym pierwszym przypadku, pisząc o skazanej na więzienie studentce Wyższej Szkoły Filmowej w Łodzi, autor nie wymienia jej nazwiska. Była to Zofia Dwornik - warto zapamiętać jej nazwisko ${ }^{17}$. Poszukiwano także i tych, którzy podczas niemieckiej okupacji mieli nieszczęście ostrzegać przed ,bolszewickim niebezpieczeństwem" (Tomasz Rusek, s. 577). Ofiarą komunistycznej dintojry padł też generał Stefan Mossor ${ }^{18}$, nie można wykluczyć, że jego wiedza o Katyniu i wstrzemięźliwe opinie dotyczące zdefiniowania sprawstwa miały istotne znaczenie w aresztowaniu i późniejszym skazaniu. Generalnie „władza ludowa” robiła wszystko, by zapobiec możliwym oskarżeniom wobec sowieckiego suwerena i zdjąć z siebie klątwę ,nieprawego pochodzenia”, co mogłoby ją moralnie delegalizować, jako ufundowaną na grobach bohaterów. Naród polski bowiem ,[...] już siedem lat kroczy jasną drogą bratniej zgody [...] z sowieckim narodem, najmocniej czuje całą podłość i obrzydliwość nowej prowokacji katyńskiej [...]” pisał Leon Kruczkowski (s. 586).

Co interesujące, sprawa katyńska posłużyła (po śmieci Stalina) do wewnętrznych rozliczeń w ZSSR. Rudenko miał oskarżyć Wsiewołoda Mierkułowa o to, że zdradził, mówiąc Berlingowi o „dużym błędzie”, jaki popełniono w odniesieniu do poszukiwanych polskich oficerów (s. 592). Rok 1956 przyniósł Polsce „odwilż”, nie zmienił jednak stosunku władz wobec „Katynia”. Gomułka reprezentował tu trudny do zaak-

17 F. Gańczak, Katyńskie piętno. Bylaby wielka montażystka - gdyby nie PRL - Przystanek Historia, 19 grudnia 2019 (online), ,[...] Dwornik wtrąciła sarkastycznie, że woli »takich zbrodniarzy, którzy nie udają przyjaciół, i jak spalą człowieka, to chociaż rodzina dostaje zawiadomienie o śmierci«. [...] Dwornikówna trafiła początkowo do gmachu WUBP przy ul. Anstadta. Później, 28 listopada, została formalnie tymczasowo aresztowana. »Śledztwo trwało trzy miesiące«. [...] Oskarżono ją z art. 22 dekretu z 13 czerwca 1946 r. o przestępstwach szczególnie niebezpiecznych w okresie odbudowy państwa. Mirosław Tomczak, oficer śledczy WUBP, zarzucał jej, że »działała na szkodę interesów Polski Ludowej i jej stosunków międzynarodowych ze Związkiem Radzieckim«. Studentka w trakcie śledztwa nie przyznawała się do winy. Koleżanki i koledzy dość zgodnie obciążyli ją jednak w trakcie przesłuchań i bezpośrednich konfrontacji. Żukowski twierdził, że Dwornik mówiła o Katyniu także przy innych okazjach [...]. [...] Proces przed Sądem Wojewódzkim dla m. Łodzi odbył się 31 stycznia 1951 r. »[...] na sali czarny, chudy prokurator w rogowych okularach, [...] zapluwał się, mieszając mnie z całym wrogim obozem imperialistycznym« - wspominała potem Dwornik. [...] została skazana na rok więzienia. »Oskarżona należy do ludzi, którym nie podoba się pokojowe i przyjacielskie współżycie Polski i Związku Radzieckiego, którym chodzi o zakłócenie tej przyjaźni« - napisano w uzasadnieniu wyroku. Część kary studentka odsiedziała w łódzkim więzieniu przy ul. Gdańskiej. W kwietniu przeniesiono ją do obozu pracy w Głazie koło Wielunia. »Był to rodzaj PGR-u, gdzie pracowały kryminalistki, a więc złodziejki, prostytutki, bajzelmamy itd.« - opowiadała już po upadku PRL”.

18 Skazany w lecie 1951 roku na dożywocie, w grudniu 1955 roku w drodze łaski zamieniono karę dożywocia na 15 lat więzienia. W kwietniu 1956 roku generała zrehabilitowano. 
ceptowania „bolesny” pragmatyzm. Był niewzruszony, nie reagując na apele o prawdę, nadchodzące z różnych stron (Julius Epstein, s. 600). W tym miejscu ponownie w opowieści Urbana pojawia się Gösta von Uexküll, który sugerował, że „[...] Hitler myślał, że będzie mógł polski naród »przerobić«, złamać jego narodową dumę, likwidując jego inteligencję. Ofiarą podobnej pomyłki musiał paść Stalin, wydając szatański rozkaz zamordowania 11000 uwięzionych polskich oficerów...” (s. 601). W kalkulacji Stalina nie było jednak miejsca na pomyłki. Decyzja katyńska nie była pomyłką, tak jak pomyłką nie była „akcja polska”. Było to działanie zamierzone. Cele mogły być różne, w ostatecznym jednak efekcie skutkowały „wyczyszczeniem” drogi do władzy w Polsce tym podporządkowanym całkowicie moskiewskiemu dyktatowi.

Przemiany 1956 roku przyniosły nieco zmian w katyńskiej dyskusji. Miało nawet dojść do dyskusji na ten temat między Chruszczowem a pragmatycznym Gomułką. Ten proponował polskiemu ,pierwszemu” ujawnienie prawdy o zbrodni. „Wiesław” zaś nie chciał zaczynać dyskusji (s. 602/603), która według niego mogłaby przynieść w ostatecznym rozrachunku spore straty, rzutujące na wzajemne polsko-sowieckie stosunki. Trzeba było więc dalej kłamać „,...] Bywają sytuacje, kiedy w imię najżywotniejszych interesów narodu nawet brudne kłamstwo należy przybierać w szaty prawdy. [...]" (s. 604). Trwało więc to kłamstwo nieprzerwanie, jako kamień węgielny położony pod fundamentami Polski Ludowej. Zaciemniano prawdę, wożąc polskie delegacje przyjeżdżające do ZSSR do miejscowości Chatyń. Od prawdy uciekali też długo Brytyjczycy, blokując inicjatywy Owena O’Malleya i przeszkadzając (nie bez udziału w tym działaniu KGB i rosyjskiej ambasady w Wielkiej Brytanii) w budowie pomnika katyńskiego w Londynie. Walka o prawdę toczyła się wszędzie - w latach siedemdziesiątych ubiegłego stulecia widziałem, jak z tablic przed Kościołem Świętego Krzyża w Warszawie „nieznani sprawcy” zrywali klepsydry z informacją o „mszach katyńskich”, na których widniała data mordu - 1940 rok. Prześladowano wydających samizdat ze wzmiankami o Katyniu. Robiono wariatów z ludzi, którzy ośmielali się publicznie protestować przeciwko katyńskiemu kłamstwu (Walenty Badylak i jego dramatyczny protest na krakowskim rynku głównym w marcu 1980 roku - s. 625). Nie do przecenienia dla pamięci o mordzie i pamięci o polskich ofiarach na Wschodzie były działania księży i świeckich (ks. Stefan Niedzielak ${ }^{19}$, Stefan Melak, s. 629 i nast.). Skutkowały wystawieniem na Powązkach (wojskowych) upamiętnienia katyńskiego w lecie 1981 roku (szybko ukradzionego przez SB) i Sanktuarium „Poległym i pomordowanym na Wschodzie” przy Kościele pw. Świętego Karola Boromeusza. Wśród osób, o których, dyskutując „o Katyniu”, powinniśmy pamiętać, należałoby wymienić Olega Zakirowa - Uzbeka, majora KGB, który mozolnie dochodził prawy o mordzie. Jego badania (s. 646, 647 i nast.) zaprzeczają powtarzanej przez Rosjan tezie o tym, że dokumentów dotyczących mordu nie ma ${ }^{20}$.

19 Autor na s. 639 sugeruje związek między tragiczną śmiercią Księdza Stefana, a jego „katyńskimi” aktywnościami. Dziś nie da się jednak jednoznacznie określić przyczyn, z jakich Ksiądz został zamordowany. Mord ten wpisuje się jednak w szereg zabójstw księży, jakie miały miejsce w 1989 roku.

20, ,...] nowe polskie kierownictwo silnie zirytowało Moskwę, gdy 12 października 1989 r. polski prokurator generalny zwrócił się do swego sowieckiego odpowiednika o wszczęcie postępowania 
Opis przekazania katyńskich dokumentów przez stronę rosyjską Wojciechowi Jaruzelskiemu darujemy sobie. Abstrahuję tu od faktu, że zaraz po dokonaniu przekazania wydano polecenie szukania jakiegoś „,anty-Katynia”. Znaleziono 18 tys. ,zamordowanych w polskich obozach” po wojnie 1920 roku „krasnoarmiejców”. Po przesileniu i faktycznym przyznaniu się do sprawstwa w Rosji nastąpiła reakcja obronna - kłamstwa i manipulacje. Rajchman miał wspominać o tym, że Stalin nakazał zabicie jeńców obawiając się tego, że ,,...] Polacy w polskich jednostkach pod niemieckim rozkazami zostaną użyci przeciwko Armii Czerwonej [...]” (s. 658/659). Łazar Kaganowicz, którego podpis widniał pod rozkazem mordu na Polakach, twierdził, że skazano na śmierć „gwałcicieli, bandytów, morderców” (s. 659). Tej zmiany narracji nie udało się powstrzymać nawet i tym, jak w roku 1993 na Powązkach Borys Jelcyn prosił o wybaczenie. Mentalnej zmiany nie udało się przeprowadzić właśnie dlatego, że narracja Jurija Muchina czy Aleksieja Millera (o tym ostatnim Urban nie wspomina, to bowiem zupełnie ,inna historia” - nowa ${ }^{21}$ ) były dla przeciętnego Rosjanina o wiele bardziej atrakcyjne niż przeprosiny i skrucha za „wystrzelanie” wspomnianych „gwałcicieli”, a na dodatek spadkobierców tych, którzy ,wymordowali” po 1920 roku ponad 80 tys. „krasnoarmiejców”.

Urban wyraża w swej pracy opinię, z której wynika, że „Katyń” jest i był „zakładnikiem polityki" 22 . Jest to opinia o tyle słuszna, że jak widać zresztą z jego pracy podejście do „katyńskiej prawdy” (nie wspominam tu o odważnych ludziach z „Memoriału”) po stronie rosyjskiej jest w sposób wyraźny pochodną nastrojów i interesów panujących w danym momencie na Kremlu. Po stronie polskiej natomiast (nie mówimy tu o okresie 1945-1989) determinantą była chęć pełnego wyjaśnienia sprawy i dotarcia do pełnej prawdy. Zupełnie dramatycznym zwieńczeniem kwestii katyńskiej stał się 10 kwietnia 2010 roku dramat na lotnisku „Siewiernyj”.

Reasumując, otrzymaliśmy książkę nasyconą wiedzą. Książkę potrzebną, powtórzmy to, bardziej w Niemczech niż w Polsce. Warto ją przeczytać. Prowokuje bowiem do refleksji nad złem, ale także i nad heroizmem w walce o prawdę - nie tylko, jak się dziś okazuje, historyczną.

karnego »z powodu zamordowania polskich oficerów w Katyniu i innych jeszcze nieustalonych miejscowościach«. W odpowiedzi zwrócono uwagę, że nie ma nowego materiału dowodowego, który podważałby wyniki komisji Burdenki z 1944 r.”, s. 648 omawianej pracy.

21 W „Polityce” (8 maja 2020) rosyjski historyk broni komunistów i atakuje Polskę w „Die Welt”: Nie powinna decydować o wspólnej europejskiej pamięci, Miller wypowiadał się też w sposób okrutnie pragmatyczny na temat kwestii „katyńskich” .

22, ,...] W rosyjskiej polityce zagranicznej nic nie dzieje się przypadkowo, a każde posunięcie rosyjskiej dyplomacji jest starannie przygotowane i obliczone na osiągnięcie konkretnych celów. [...] najważniejsza jest konstatacja, że długoterminowym celem władz rosyjskich jest uniemożliwienie Polsce prowadzenia aktywnej polityki wschodniej. Jest ona bowiem na ogół sprzeczna z interesami imperialnej Rosji...”. A. Nowak, Prywatna zbrodnia Stalin, „Rzeczpospolita”, 30 listopada 2010 (online). 